\title{
Thymic stromal lymphopoietin promotes human eosinophil-basophil lineage commitment: a key role for tumor necrosis factor-alpha
}

\author{
Claudia CK Hui*, Sina Rusta-Sallehy, Delia Heroux, Judah A Denburg \\ From Canadian Society of Allergy and Clinical Immunology Annual Scientific Meeting 2013 \\ Toronto, Canada. 3-6 October 2013
}

\section{Background}

Allergic diseases are characterized by tissue eosinophilic and basophilic inflammation. Both epithelial-derived thymic stromal lymphopoietin (TSLP) and eosinophil/ basophil (Eo/B) lineage-committed progenitor cells are upregulated and found at sites of allergic inflammation [1-3]. We have previously shown that TSLP mediates the differentiation of peripheral blood (PB) $\mathrm{CD}_{3} 4^{+}$progenitor cells into eosinophils and basophils. However, the specific mechanisms through which TSLP promotes this lineage commitment are unclear. The aim of this study is to characterize the intracellular mechanisms by which TSLP mediates Eo/B differentiation.

\section{Methods}

Purified PB CD $34^{+}$progenitors were stimulated overnight with media, IL-3 $(1 \mathrm{ng} / \mathrm{mL})$, TSLP $(10 \mathrm{ng} / \mathrm{mL})$, or IL-3/TSLP and assessed for cytokine and chemokine secretion using Luminex assays. Alterations in Eo/B colony forming units (CFU) and surface expression of TSLPR post-stimulation with IL-3/TSLP (and/or neutralizing anti-TNF $\alpha \mathrm{Ab}$ ) were assessed by methylcellulose cultures and flow cytometry respectively.

\section{Results}

TSLP alone induced significant levels of IL-1 $\beta$, IL-6, TNF $\alpha$, and CXCL8 from PB CD34 ${ }^{+}$cells, compared to unstimulated controls $(\mathrm{p}<0.05)$. IL-3/TSLP-stimulated $\mathrm{CD}_{4}{ }^{+}$cells released significant levels of IL- $1 \beta$, IL- 6 , IL13, TNF $\alpha$, CXCL8 8 and CCL2, but failed to secrete detectable levels of IL-4, IL-9, GM-CSF, IFN $\gamma$, and eotaxin. Blockade of TNFa in vitro in the differentiation

\footnotetext{
* Correspondence: huicck@mcmaster.ca
}

Department of Medicine, McMaster University, Hamilton, ON, Canada assays inhibited both TSLPR expression $(\mathrm{p}<0.05)$ and IL-3-responsive Eo/B CFU formation $(\mathrm{p}<0.05)$. Overnight stimulation of PB CD34 $4^{+}$cells with IL-3 (10ng/ $\mathrm{mL})$ and $\mathrm{TNF} \alpha(50 \mathrm{pg} / \mathrm{mL})$ enhanced surface expression of TSLPR to comparable levels post TSLP/IL-3-stimulation. Moreover, pre-stimulating CD $34^{+}$cells with IL-3/ TNF $\alpha$ prior to culturing in methylcellulose cultures resulted in enhanced sensitivity to TSLP-mediated Eo/B colony formation at lower concentrations of TSLP.

\section{Conclusions}

We have previously shown that stimulation of human PB CD34+ cells with TSLP promotes Eo/B differentiation through upregulation of IL-3R $\alpha$ and TSLPR. Our current study demonstrates that TSLP can modulate Eo/ B lineage commitment, by inducing PB CD34 ${ }^{+}$cells to actively secrete chemokines and cytokines (key among which is TNF $\alpha$ ), which, together with IL-3, induce the upregulation of TSLPR, leading to the subsequent amplification of Eo/B CFU. The novel role of TSLPinduced Eo/B differentiation points to the importance of the epithelium, and its responses to environmental stimuli, in the development of allergic diseases.

\section{Acknowledgements \\ This work is funded by CIHR, AllerGen NCE (CAIDATI Award), McMaster University (Medicine Graduate Initiative Fund).}

Published: 3 March 2014

\section{References}

1. Ying S, O'Connor B, Ratoff J, Meng Q, Mallett K, Cousins D, et al: Thymic stromal lymphopoietin expression is increased in asthmatic airways and correlates with expression of Th2-attracting chemokines and disease severity. J Immunol 2005, 174:8183-90.

2. Robinson DS, Damia R, Zeibecoglou K, Molet S, North J, Yamada T, et al: CD34(+)/interleukin-5Ralpha messenger RNA+ cells in the bronchial 
mucosa in asthma: potential airway eosinophil progenitors. Am J Respir Cell Mol Biol 1999, 20:9-13.

3. Kim YK, Uno M, Hamilos DL, Beck L, Bochner B, Schleimer R, et al: Immunolocalization of CD34 in nasal polyposis. Effect of topical corticosteroids. Am J Respir Cell Mol Biol 1999, 20:388-97.

doi:10.1186/1710-1492-10-S1-A51

Cite this article as: Hui et al: Thymic stromal lymphopoietin promotes human eosinophil-basophil lineage commitment: a key role for tumor necrosis factor-alpha. Allergy, Asthma \& Clinical Immunology 2014 10(Suppl 1):A51.

Submit your next manuscript to BioMed Central and take full advantage of:

- Convenient online submission

- Thorough peer review

- No space constraints or color figure charges

- Immediate publication on acceptance

- Inclusion in PubMed, CAS, Scopus and Google Scholar

- Research which is freely available for redistribution

Submit your manuscript at www.biomedcentral.com/submit
C) Biomed Central 